\title{
Study Benefits of Smartphones: Perceptions of Female Emirati Pre-Service Teacher Undergraduates
}

\author{
Nicolas Gromik ${ }^{1, *}$ and David Litz ${ }^{2}$ (1) \\ 1 College of Indigenous Futures, Education and Arts (CIFEA), Charles Darwin University, \\ Darwin 0810, Australia \\ 2 School of Education, University of Northern British Columbia, Prince George, BC V2N 4Z9, Canada; \\ david.litz@unbc.ca \\ * Correspondence: Nicolas.gromik@cdu.edu.au
}

Citation: Gromik, N.; Litz, D. Study Benefits of Smartphones: Perceptions of Female Emirati Pre-Service Teacher Undergraduates. Educ. Sci. 2021, 11, 817. https://doi.org/10.3390/ educsci11120817

Academic Editors: Piret Luik and Marina Lepp

Received: 2 November 2021

Accepted: 10 December 2021

Published: 16 December 2021

Publisher's Note: MDPI stays neutral with regard to jurisdictional claims in published maps and institutional affiliations.

Copyright: (c) 2021 by the authors. Licensee MDPI, Basel, Switzerland. This article is an open access article distributed under the terms and conditions of the Creative Commons Attribution (CC BY) license (https:// creativecommons.org/licenses/by/ $4.0 /)$.

\begin{abstract}
Smartphones are becoming ubiquitous and can be very useful study tools. We explored female Emirati undergraduates' perceptions of smartphone use in the classroom. Furthermore, we investigated the age at which participants received their first smartphones, the number of smartphones to which they had access at the time of the study, and the influence of these aspects on the use of smartphones as a learning tool. An online survey of 189 participants revealed that the age of receiving their first smartphone, combined with the number of smartphones they owned or had access to at the time of the study, did not correlate with their perceptions of the usefulness of smartphones as a learning tool in a statistically significant manner. However, participants in their first year of study had fewer positive perceptions about the use of smartphones in the classroom than participants in subsequent study years. We surmise that this might be attributable, in part, to the further experiences older students have had or classes they have taken or to student teaching experiences in which they might have firsthand observed the benefits of phone use in the classroom as a learning tool.
\end{abstract}

Keywords: smartphones; educational tools; classroom technology; United Arab Emirates; preservice teachers

\section{Introduction}

Digital natives have spent their entire lives surrounded by digital technology, and in today's increasingly tech-centered world, a growing number of people, especially younger people, can be identified as part of this cohort. As Prensky [1] pointed out, there are many ways in which the digital has become part of the norm: "computer games, email, the Internet, cell phones and instant messaging" (p. 1) are central to the lives of digital natives. McNeely [2] refers to these digital natives as members of the Net Generation. These people, including students, might be able to, for example, play video games and listen to music simultaneously in any location, context, or time without impacting their surroundings or affecting their peers. While popular opinion may deride this generation as constantly seeking stimuli, unable to concentrate, or even addicted to screens, there are undeniable benefits to such digital access, many of which belong to the learning domain. These learners can now take advantage of the digitally afforded freedom of smartphones to engage in online activities, academic communities, and websites that can result in independent learning or supplement classroom education [3]. These activities are no longer solely defined by curriculum; an entire world of data and information is available to today's population, and both teachers and students can take advantage of it to transform learning processes.

Learning is now driven not only by formal curricula and the norms and mores of the classroom but also by the learners' desire to understand a topic that is important to 
them and can fulfill their needs, whether practical or for purposes of self-actualization [2]. Technology, then, can enhance students' learning in a myriad of ways.

Digital technology can be accessed in various contexts and with a plethora of devices, but smartphones are an increasingly important tool for accessing the Internet and all it has to offer. Norris et al. [4] describe smartphones as essential tools for learning [5]. The accessibility of smartphones today is one of the major reasons that they are considered as essential learning tools. One aspect not foreseen by Prensky and other scholars is the fact that nearly all learners now have access to a smartphone. This is particularly true in the United Arab Emirates (UAE), which has the world's highest concentration of smartphones: in a total population of $9,770,000$, there are a reported 19,602,000 mobile cellular subscribers of all types of portable phones [6,7]. It is notable that some subscribers have access to more than one phone or device, which might skew this number somewhat. Accordingly, the number of smartphones to which a learner has access is one of the areas explored in this study.

A 2012 data analysis of smartphone ownership in the UAE, conducted by Ipsos OTX MediaCT [7] reported that $28 \%$ of those aged $18-24,44 \%$ of those aged $25-34,20 \%$ of those aged $35-44$, and $8 \%$ of those aged $45-54$ had smartphones. Only $1 \%$ of the respondents aged 55 years and above had smartphones [8]. The 2018 Symantec Report [8] indicated that $31 \%$ of young adults aged $5-10$ owned a smartphone and $70 \%$ of subscribers aged 11-16 owned a smartphone, with the average age of smartphone ownership being nine in the UAE. Clearly, this generational gap persists, but the percentage of younger people with smartphones is high and growing. Simultaneously, the issue of whether and how smartphones can best be used as an educational tool will only continue to grow in importance and scope, and projects such as this one will add to the body of knowledge about how to use this new world of technological innovation to ensure the best possible outcomes for learners and, thus, for society at large as we continue into the digital age.

\subsection{Gender-Based Aspects of Smartphone Usage}

In the earlier days of the internet, there was a great deal of research on the perceived digital divide between men and women, first in computer and internet usage in general and, more recently, on the use of, comfort with, and ownership of smartphones. However, "the appeal of the smartphone itself is known to be gender-neutral" [9] (p. 417), with platform design mattering more than gender in terms of smartphone preferences [10]. With gender differences being largely irrelevant, it might be more informative to define the differences between game, app, and activity designs as impacting either older or younger players or subscribers. Jenkin [11] quoted an 84-year-old female player as stating that computer games "keep [me] very active and alert" (p. 1). Certainly, age, as opposed to gender, is an area of ongoing research area with regard to technology use in general and smartphone use in particular.

In fact, in the final analysis, the possibility that gender differences explain smartphone behaviors-or other behaviors related to access to or use of technology—appears to become subservient to the concept that age might be the demographic marker that defines, or at least in some way correlates with, response to smartphone behaviors.

\subsection{Age-Based Research}

While gender-based research could still apply to human-computer interaction in general, technology, web, and app development are more focused on the user experience based on age. Human-computer interaction focuses mainly on age groups and their experiences with and usage of technology as well as their comfort level [12]. For example, findings regarding the impact of screen size on various age groups have been reported: participants aged 60 years and above seemed to face greater challenges with a smaller screen size than participants aged 20-39 [12]. Perhaps related to this, a correlation between accessing a smartphone at a young age and poor eyesight later in life has been suggested [13]. It is possible that screen size, then, will become more of an issue as the current population, who 
have been using smartphones for a larger percentage of their lives, ages. The impact of smartphone use on the aging process is an area of research that certainly would benefit from further focus by the scholarly community.

Computer-focused research, along with research about technology in general, seems to place a greater emphasis on age than on many other demographic markers. Such focused interest may be warranted, especially based on a report that, by 2050, the number of older adults would be two billion [14]. Older participants seem to manage their smartphone use in some ways better than their younger counterparts, and they are less likely to overuse the technology [9]. For example, the younger generation seems more profligate and more likely to overindulge in social network usage.

\subsection{Current State of Smartphone Access}

In order to understand learners' current and ideal use of technology for educational purposes, it is important to understand the current state of smartphone access. How much of a difference this sort of technology can make depends almost entirely on whether or not it is truly widely accessible, and if not to all, then to whom it is available. Today, the iPhone, as well as Samsung and Huawei products, can be accessed by a large number of learners from almost any country through a variety of public and private web services. In the past, students spent up to 10,000 $\mathrm{h}$ across their lifetime playing video games [1], but the post-Prensky (Marc Prensky is known for popularizing the terms 'digital native' and 'digital immigrant' in his 2001 article entitled Digital Natives, Digital Immigrants, in which he relates shortcomings in education to educators' failure to understand the needs of modern students. His article posited that the arrival and rapid dissemination of digital technology in the last decade of the 20th century had altered the manner students think and process information, making it difficult for them to excel academically using outdated teaching methods) digital generation may have 10,000 $\mathrm{h}$ or more of smartphone access within their lifetime. Park and Park [15] indicate that Korean respondents spend $4 \mathrm{~h}$ on their phone on average. This would equate to $14,000 \mathrm{~h}$ over ten years (also see [16] for Indian context). The speed at which smartphone subscribers can now access content has also increased their reflective learning experience when selecting a product or service. Today, research continues to seek to understand the digital native, migrant, or nomad population. Research is now focused on this specific population and explores culturally specific contexts of use, including differences in users' demographics, as discussed above. Digital natives are growing older, and the younger ones will have increased access to newer and more powerful devices [1]. The current direction of research aims to understand, among other things, whether age is still a factor when describing digital learners. If age is a factor, it may be possible to determine whether it will have less impact as smartphones become increasingly universal.

As technology and connection subscriptions become more financially accessible to the general public, the number of people with access to smartphones is increasing. In 2015, there were seven billion people with access to a mobile or cellular phone; this number represents a $96.8 \%$ penetration rate [15]. For the same period, 84 million people specifically in the Arab States had access to a mobile or cellular phone [16]. In 2019, there were 19,602,815 mobile phone subscribers [16,17], and by 2025, there will be an additional 459 million unique mobile subscribers [17] (p. 4). Clearly, their use by all gender demographics and age groups makes it evident that smartphones may well be a tool for learning both inside and outside the classroom.

\subsection{Mobile Learning}

There are various methods for accessing mobile learning online, and there are several forms of online learning, with more different apps, programs, and modalities seemingly being developed every day. Given that the definition of learning used in this study includes both officially sanctioned or direct learning led by an instructor and personal learning that 
is both formal/informal and self-directed, the use of mobile learning is quite broad. Mobile learning is, thus, discussed in this literature review in a general manner.

McGregor and Bartle [18] point out that mobile learning can include the use of game technology. Specifically, they reviewed the use of game technology to stimulate learning in the ethics field in postgraduate classes; thus, the use of games for learning is not limited to those that are very young. However, this modality may hold special appeal or even be particularly effective in young students. Ciampa [19] researched the impact of mobile learning on grade six students; the single-case study of one teacher's classroom explored the teacher's impressions of how online technologies motivate students. The tool used was a tablet, and the study specifically investigated how students and teachers perceived the impact of tablet use on student learning motivation. One key finding was that having the tablet allowed students to work at their own pace and control parts of their education, resulting in a generally positive impact on learning motivation because of increased self-efficacy.

Although more has been conducted in the intervening years, there is a lack of use of mobile educational technologies in teacher universities and educational centers [20,21]. This may represent a significant weakness or potential area of growth for teacher education given the tendency of school systems to emphasize the use of mobile learning devices in the classroom [20]. Instructors can also assess student participation online, have conversations with students, communicate with other teachers and supervisors, and can do so both synchronously and asynchronously [20]. Therefore, it makes sense that teachers must be able to use this technology comfortably themselves. It must be taught in pre-service education for its effective implementation by teachers for use by their students and within their own classrooms and learning plans. As we face the coronavirus pandemic that has disrupted education worldwide, it is even clearer how important learning with technology and especially mobile devices can be.

The ability to determine the location of users, access social networks, search the web, detect motion, and even enter augmented reality adds to the ability of smartphones to improve learning and classroom engagement $[22,23]$. These features are present in many of today's smartphones as well as in desktop computers. The ability to communicate with groups using features such as Messenger and to interact with other students in Moodle classrooms, whiteboard settings, and even Skype sessions can keep students interested in the classroom and connected with other students, increasing their intrinsic motivation. These activities can be conducted on a desktop computer, but more and more people are progressing towards the mobile way, and the fact that mobile devices have entered schools and classrooms should not only be tolerated but also taken advantage of by educators. In short, "mobile learning enables teachers and learners ubiquitous and seamless access to information" [20] (p. 18). While the information must be somewhat regulated to keep it educational and appropriate, it is difficult to see how introducing such a powerful tool to the classroom and the broader world of learning could be anything but a net positive.

However, not everyone agrees. Those who study the use of mobile learning systems in the classroom suggest that many school systems treat the use of mobile learning in K-12 classrooms as "a disruptive force." As a result, the potential plusses of these devices and this modality of learning are excluded from classrooms [24] (p. 32). Teachers' impressions of mobile phones in the classroom were reportedly more likely to be negative if the teacher was over the age of $50[24,25]$. Furthermore, while $45 \%$ of pre-service teachers in the US state of Kentucky supported mobile phones being used in the classroom, 25\% did not support their use, and 30\% were not certain of their efficacy as learning tools [26] (p. 113). Most of the study population, in this case, was young, since the study concerned preservice teachers. In fact, in the UAE, $65 \%$ of parents indicate that personal smartphones are banned [19] (p. 42). However, while smartphones present challenges in the classroom, they also offer several opportunities [27]; the recording function is particularly beneficial [28]. According to current research, elementary school teachers are more likely to use mobile learning systems than are middle and high school teachers [29]. Ultimately, however, more research is needed to examine how teachers see smartphone use in the classroom so that 
best practices in teacher education can be put into place. This study accordingly aimed to understand more about teachers' perceptions of smartphone use for learning.

\section{Materials and Methods}

\subsection{Research Questions}

General research into smartphone ownership in the Middle East report on adoption for specific purposes (for example, adoption of smartphone as evidence for business analytics [30]). Other research reports have assessed the use of smartphones as pedagogic tools for emailing, knowledge sharing, and using social media applications [31]. Similarly to previous research, the context of this study is higher education. However, the difference lies in the cohort selected $(\mathrm{F}=189)$ as well as their academic background. All respondents were enrolled in a Bachelor of Education program. The primary research question, set within the UAE educational college context, was as follows.

To what extent does the age of access to a smartphone influence pre-service teacher's perceptions about using a smartphone to learn?

The secondary questions were as follows.

To what extent does the age of access to a smartphone influence pre-service teachers' perceptions of the usefulness of smartphones for learning?

What are UAE pre-service teacher undergraduates' perceptions regarding their intentions to use smartphones for teaching or in their future studies?

\subsection{Methodology}

\subsubsection{Ethical Consideration}

An ethical clearance was submitted and successfully received. All participants were invited to agree or disagree in participating in the survey by indicating consent. Participants who provided their approval to participate proceeded to complete the survey.

\subsubsection{Pilot Study}

For the pilot study, the questions were reviewed by a colleague familiar with the students' English abilities to ensure that they would be clear. The questions were also tested for reading comprehensibility. Two year-3 students, two year-2 students, and two year-1 students (all women) were randomly selected to read the survey and identify unfamiliar words. The statements used were generally easily understood. However, a few words needed to be changed. For example, "My smartphone is an efficient learning tool" was changed to "I find my smartphone easy to use." While the two statements are different, the latter was considered less confusing and more in line with the technology acceptance model. After completing the questionnaire, students were invited to rate the questions. Students indicated that having a rating scale as a method of answering was better than having short answer responses. A rating system enabled them to quickly complete the questionnaire and feel confident in their responses. Upon discussion, the research team decided that owing to the low number of male students on campus $(n=20)$ and their low rate of responses to previous surveys, the target audience would be female participants.

\subsubsection{Survey Administration}

After revision based on the results of the pilot study, the survey was uploaded to Qualtrics, an online survey website [32]. A link was emailed to all campus students, inviting them to respond to the survey. The digital cover page included a statement on the study's background and purpose. Students were asked to select whether they would be willing to complete the survey. All students received two email reminders inviting them to respond to the survey. On the last day of academic studies, one last reminder was sent. One week after the end of the academic term, the survey was closed, and the data were then extracted and sorted. 


\subsubsection{Participants}

A total of 225 female students responded to the survey. While six students indicated that they did not wish to participate, 219 students agreed to complete the survey. Thirty students had not provided complete responses; thus, their data were discarded. The responses of the remaining 189 participants were analyzed.

\subsubsection{Data Analysis}

Once the data were retrieved from Qualtrics, they were analyzed using SPSS [33] to explore descriptive statistics and quantify the demographics of the study sample as well as their perceptions. Once descriptive statistics were reviewed, Cronbach's alpha and the goodness of fit were examined to validate whether the correlation and $t$-test analyses revealed any influencing items regarding the participants' perceptions [34].

\section{Results}

\subsection{Descriptive Analysis}

The first analysis regarded students' self-ratings of their English abilities (Table 1) as it validates the reliability of the answers provided.

Table 1. Cross-tabulation between age group and overall self-rating of English ability.

\begin{tabular}{cccccc}
\hline & \multicolumn{3}{c}{ Overall Self-Rating of English Ability } & \multirow{2}{*}{ Total } \\
\cline { 2 - 5 } & Acceptable & Suitable & Good & Excellent & \\
\hline $21-23$ & 48 & 9 & 3 & 0 & 60 \\
$24-26$ & 24 & 5 & 2 & 1 & 32 \\
$27-29$ & 7 & 5 & 1 & 0 & 13 \\
$30-32$ & 7 & 0 & 0 & 0 & 7 \\
$33-35$ & 5 & 1 & 0 & 0 & 6 \\
$36-38$ & 3 & 1 & 0 & 0 & 4 \\
Total & 157 & 25 & 6 & 1 & 189 \\
\hline
\end{tabular}

As Table 1 indicates, only one participant self-rated their overall English ability to be excellent, while six self-perceived it to be good. Twenty-five participants perceived their overall ability to be suitable, while the remaining thought their English ability was acceptable for academic participation $(n=157)$. Based on the self-rating in Table 1 , it appeared that students would be able to complete this survey with the confidence that they correctly understood the task and questions. The next analysis was to compare the years of study and age groups (Table 2).

Table 2. Cross-tabulation between age group and year of study.

\begin{tabular}{|c|c|c|c|c|c|c|}
\hline & & \multicolumn{4}{|c|}{ Year of Study } & \multirow{2}{*}{ Total } \\
\hline & & Year 1 & Year 2 & Year 3 & Year 4 & \\
\hline \multirow{7}{*}{ Age Group } & $18-20$ & 49 & 18 & 0 & 0 & 67 \\
\hline & $21-23$ & 22 & 13 & 15 & 10 & 60 \\
\hline & $24-26$ & 7 & 5 & 11 & 9 & 32 \\
\hline & $27-29$ & 0 & 4 & 7 & 2 & 13 \\
\hline & $30-32$ & 0 & 2 & 4 & 1 & 7 \\
\hline & $33-35$ & 0 & 1 & 3 & 2 & 6 \\
\hline & $36-38$ & 0 & 2 & 0 & 2 & 4 \\
\hline \multicolumn{2}{|c|}{ Total } & 78 & 45 & 40 & 26 & 189 \\
\hline
\end{tabular}

As Table 2 indicates, many of the participants were aged 18-26 $(n=159)$. The single biggest group of participants included individuals in their first year of study $(n=78)$. The table demonstrates that the participants were spread relatively equally across the four-year levels, rendering the data more generalizable. 
As Table 3 below shows, almost half of the participants in year 1 received their first smartphone between 16 and 20 years of age and owned one smartphone $(n=58)$. Of note is that this age category is also the largest $(n=118)$. The next biggest group of participants in this age group owned two smartphones $(n=44)$. Another observation is that 83 participants reported owning one smartphone compared to other peers who reported owning two or more smartphones $(n=106)$.

Table 3. Cross-tabulation between age of access to first smartphone and number of smartphones owned.

\begin{tabular}{cccccccc}
\hline & & \multicolumn{8}{c}{ How Many Smartphones Do You Own or Have Access to? } & \multirow{2}{*}{ Total } \\
\cline { 3 - 7 } & & $\mathbf{1}$ & $\mathbf{2}$ & $\mathbf{3}$ & $\mathbf{4}$ & More Than $\mathbf{5}$ & \\
\hline \multirow{2}{*}{ Age of } & $1-5$ & 3 & 2 & 4 & 0 & 0 & 9 \\
access to first & $6-10$ & 2 & 3 & 5 & 1 & 2 & 13 \\
smartphone & $11-15$ & 14 & 12 & 6 & 0 & 3 & 35 \\
(years) & $16-20$ & 58 & 44 & 11 & 3 & 2 & 118 \\
Total & $\geq 21$ & 6 & 5 & 0 & 3 & 0 & 14 \\
& & 83 & 66 & 26 & 7 & 7 & 189 \\
\hline
\end{tabular}

Participants with access to a smartphone at a younger age did not seem to have access to more smartphones than participants in other age groups; thus, the age of first smartphone usage did not seem to impact the number of smartphones accessible to the participant at the time of the study. Some participants also seemed to have gained access to a smartphone at a relatively young age; 14 were aged 11-15 when they acquired phones, and five were aged 1-10. In comparison, only six participants were unable to access smartphones at the age of 21 or older.

Additionally, a correlation analysis was conducted to explore the relationship between the number of smartphones owned by participants and the age at which they first had access to them.

As Table 4 reveals, there was a significant negative correlation between the ages at which participants received their first smartphones and the number of smartphones they could currently access. The evidence seems to suggest that the younger the participants were when they received their first phone, the more smartphones they could currently access; for older participants, this finding was reversed. This result makes sense on an intuitive level, as students who had access to a smartphone at an early age likely grew up in families that were comfortable with and able to afford technology. These demographics probably did not change significantly as students became older. Once a person has access to a smartphone, it was very unusual for them to give it up; thus, those who adopted this technology earlier and came from families that did the same would logically be more likely to have access to more than one smartphone.

The premise of this study is to evaluate participants' perceptions of smartphone use for learning. The next analysis reports on cross-tabulation between age of access to a smartphone and opinion on the use of smartphones in class (Table 5). The first noticeable finding was that the age of access to a smartphone did not mean participants were most likely to agree that students should use smartphones in class (strongly agree, $n=2$; agree, $n=2$; and strongly disagree, $n=2$ ). The second noticeable finding was that students who had smartphone access between 16 and 20 years of age had the strongest opinions on the matter. Overall, nine participants strongly agreed, 35 agreed, 40 neither agreed nor disagreed, 18 disagreed, and 16 strongly disagreed that students should use their smartphone in class. The "Total" row in Table 5 above reveals an expected distribution between the categories (Strongly agree $=20$, Agree $=55$, Neither agree nor disagree $=59$, Disagree $=29$, and Strongly disagree $=26)$. The evidence indicates that $39 \%(n=75)$ either strongly agreed or agreed, 31\% $(n=59)$ were uncertain, and 29\% $(n=55)$ either disagreed or strongly disagreed. Thus, there was a lack of consensus among current students regarding the use of smartphones in the classroom. Further research on early access to smartphones 
is warranted for determining students' consideration of the benefits, potential downsides, or both of the use of smartphones for learning and eventually teaching. It also remains to be seen whether such research findings influence their opinions or, if presented to them after the survey, change their opinions in a similar future survey.

Table 4. Correlation between access to smartphones and first ownership.

\begin{tabular}{cccc}
\hline & & $\begin{array}{c}\text { How Old Were You When } \\
\text { You Received Your First } \\
\text { Smartphone? }\end{array}$ & $\begin{array}{c}\text { How Many Smartphones Do } \\
\text { You Own or Have Access to? }\end{array}$ \\
\hline $\begin{array}{c}\text { How old were you when you } \\
\text { received your first } \\
\text { smartphone? }\end{array}$ & $\begin{array}{c}\text { Pearson's correlation } \\
\text { Sig. (2-tailed) } \\
n\end{array}$ & 1 & $-0.199 * *$ \\
& $n$ & 189 & 0.006 \\
How many smartphones do & Pearson's correlation & Sig. (2-tailed) \\
you own or have access to? & $n$ & $-0.199 * *$ & 1 \\
\hline
\end{tabular}

** Correlation is significant at the 0.01 level (two-tailed).

Table 5. Cross-tabulation between age of access to a smartphone, year level, and opinion regarding smartphone use in the classroom.

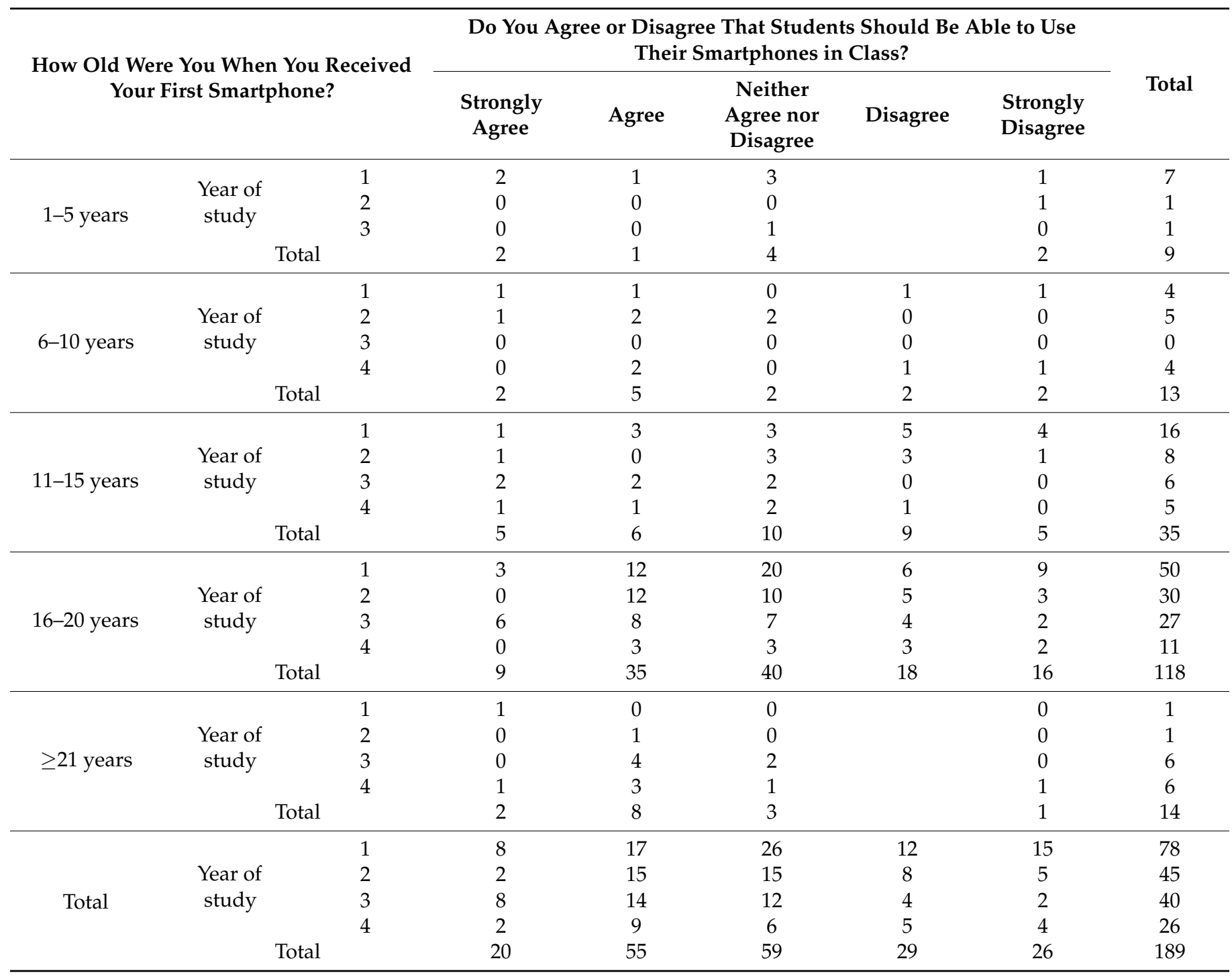


In order to further understand students' perceptions of the educational merits of smartphones, additional analyses were conducted. Eight questions relating to perceptions of the benefits of using a smartphone obtained a Cronbach's alpha value of 0.866 , which is above the required seven and considered reliable [35]: (1) A smartphone is a useful learning device; (2) a smartphone makes learning easier; (3) I find all smartphones easy to use; (4) it would be easy for me to learn something on my smartphone; (5) learning on my smartphone is easy for me; (6) my smartphone is user-friendly for learning; (7) I like learning with my smartphone; and (8) I believe that all students should study with their smartphones. No statement was rejected to achieve a higher Cronbach's alpha score. The reported $\mathrm{x}^{2}$ value of $55.2, \mathrm{df}=7$, was found to have an associated probability value of 0.0001 , meaning that selected questions and their response types were not equally popular.

\subsection{Correlation Results}

Two correlation analyses among the eight items were conducted. Table 6 reports on the correlation between items, and Table 7 investigates age of access and self-perception of smartphones. Table 6 reveals that each survey response had a positive correlation with the other items selected. The participants perceived the useful operation of smartphones to be conducive to positive use and learning.

Table 6. Inter-items correlation analysis of respondents' smartphone use self-perception.

\begin{tabular}{|c|c|c|c|c|c|c|c|c|}
\hline & & 2 & 3 & 4 & 5 & 6 & 7 & 8 \\
\hline 1. & A smartphone is a useful learning device & $0.687^{* *}$ & $0.206^{* *}$ & $0.484^{* *}$ & $0.557 * *$ & $0.533 * *$ & $0.430 * *$ & $0.435^{* *}$ \\
\hline 2. & Using my smartphone makes learning easier & - & 0.127 & $0.551^{* *}$ & $0.587^{* *}$ & $0.471^{* *}$ & $0.464^{* *}$ & $0.465^{* *}$ \\
\hline 3. & I find all smartphones easy to use & & - & $0.194^{* *}$ & 0.123 & $0.146^{*}$ & 0.024 & $0.159 *$ \\
\hline 4. & $\begin{array}{l}\text { It would be easy for me to learn something } \\
\text { on my smartphone }\end{array}$ & & & - & $0.711^{* *}$ & $0.732 * *$ & $0.542^{* *}$ & $0.393^{* *}$ \\
\hline 5. & Learning with my smartphone is easy for me & & & & - & $0.729 * *$ & $0.576^{* *}$ & $0.494^{* *}$ \\
\hline 6. & $\begin{array}{l}\text { I find learning on my smartphone to be } \\
\text { user-friendly }\end{array}$ & & & & & - & $0.582 * *$ & $0.495^{* *}$ \\
\hline 7. & I like learning with my smartphone & & & & & & - & $0.597^{* *}$ \\
\hline 8. & $\begin{array}{l}\text { I believe that all students should study with } \\
\text { their smartphone }\end{array}$ & - & - & - & - & - & - & - \\
\hline
\end{tabular}

* Correlation is significant at the 0.05 level ( 2 tailed). ${ }^{* *}$ Correlation is significant at the 0.01 level ( 2 tailed).

However, as Table 7 shows, there was no correlation between the age at which participants accessed their first cell phones and any selected items.

The results indicate that the age of access to a smartphone did not seem to correlate with participants' perceptions of the educational benefits of these devices. Thus, a one-way analysis of variance (ANOVA) was conducted in order to gain a better understanding of the students' perceptions of the smartphone as a learning tool. 
Table 7. Correlation between age of access and smartphone use self-perception.

\begin{tabular}{|c|c|c|c|c|c|c|c|c|c|}
\hline & & 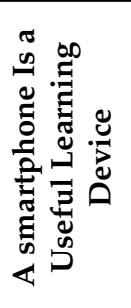 & 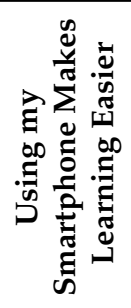 & 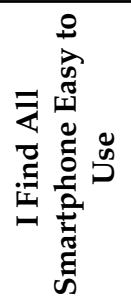 & 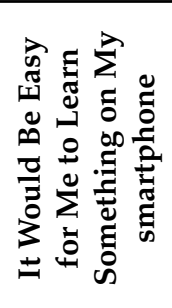 & 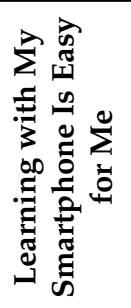 & 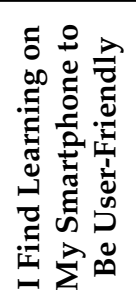 & 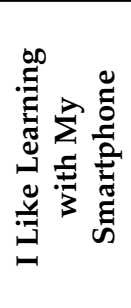 & 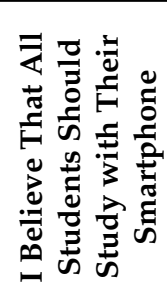 \\
\hline \multirow{3}{*}{$\begin{array}{l}\text { How old were } \\
\text { you when you } \\
\text { received your } \\
\text { first smartphone? }\end{array}$} & $\begin{array}{l}\text { Pearson's } \\
\text { correla- } \\
\text { tion }\end{array}$ & -0.072 & -0.013 & 0.005 & 0.046 & -0.006 & 0.124 & 0.004 & 0.003 \\
\hline & $\begin{array}{c}\text { Sig. } \\
\text { (2-tailed) }\end{array}$ & 0.327 & 0.855 & 0.950 & 0.527 & 0.931 & 0.089 & 0.955 & 0.966 \\
\hline & $n$ & 189 & 189 & 189 & 189 & 189 & 189 & 189 & 189 \\
\hline
\end{tabular}

\subsection{One-Way ANOVA}

A one-way ANOVA (see Table 8 below) was conducted to further analyze participants' perceptions of smartphones' educational benefits based on their age because the results can help "determine whether there are any significant differences between the means" among a group of students ([35], para 1). The evidence suggested that there were correlations between items and no correlations between age of access and any of the items selected.

Table 8. ANOVA to investigate age of access.

\begin{tabular}{|c|c|c|c|c|c|c|}
\hline & & $\begin{array}{l}\text { Sum of } \\
\text { Squares }\end{array}$ & df & Mean Square & F & Sig. \\
\hline \multirow{3}{*}{$\begin{array}{l}\text { A smartphone is a useful } \\
\text { learning device }\end{array}$} & Between groups & 7.184 & 6 & 1.197 & 1.241 & 0.287 \\
\hline & Within groups & 175.621 & 182 & 0.965 & & \\
\hline & Total & 182.804 & 188 & & & \\
\hline \multirow{3}{*}{$\begin{array}{l}\text { Using my smartphone } \\
\text { makes learning easier }\end{array}$} & Between groups & 4.387 & 6 & 0.731 & 0.684 & 0.663 \\
\hline & Within groups & 194.481 & 182 & 1.069 & & \\
\hline & Total & 198.868 & 188 & & & \\
\hline \multirow{3}{*}{$\begin{array}{l}\text { I find all smartphones } \\
\text { easy to use }\end{array}$} & Between groups & 3.540 & 6 & 0.590 & 0.615 & 0.718 \\
\hline & Within groups & 174.598 & 182 & 0.959 & & \\
\hline & Total & 178.138 & 188 & & & \\
\hline \multirow{3}{*}{$\begin{array}{l}\text { It would be easy for me } \\
\text { to learn something on } \\
\text { my smartphone }\end{array}$} & Between groups & 7.159 & 6 & 1.193 & 1.137 & 0.342 \\
\hline & Within groups & 190.947 & 182 & 1.049 & & \\
\hline & Total & 198.106 & 188 & & & \\
\hline \multirow{3}{*}{$\begin{array}{l}\text { Learning with my } \\
\text { smartphone is easy for } \\
\text { me }\end{array}$} & Between groups & 5.455 & 6 & 0.909 & 0.768 & 0.596 \\
\hline & Within groups & 215.498 & 182 & 1.184 & & \\
\hline & Total & 220.952 & 188 & & & \\
\hline \multirow{3}{*}{$\begin{array}{l}\text { I find learning on my } \\
\text { smartphone to be } \\
\text { user-friendly }\end{array}$} & Between groups & 9.970 & 6 & 1.662 & 1.706 & 0.122 \\
\hline & Within groups & 177.269 & 182 & 0.974 & & \\
\hline & Total & 187.238 & 188 & & & \\
\hline \multirow{3}{*}{$\begin{array}{l}\text { I like learning with my } \\
\text { smartphone }\end{array}$} & Between groups & 9.358 & 6 & 1.560 & 1.338 & 0.242 \\
\hline & Within groups & 212.081 & 182 & 1.165 & & \\
\hline & Total & 221.439 & 188 & & & \\
\hline \multirow{3}{*}{$\begin{array}{l}\text { I believe that all students } \\
\text { should study with their } \\
\text { smartphones }\end{array}$} & Between groups & 9.565 & 6 & 1.594 & 1.103 & 0.362 \\
\hline & Within groups & 262.985 & 182 & 1.445 & & \\
\hline & Total & 272.550 & 188 & & & \\
\hline
\end{tabular}

The ANOVA reported no significant difference between means, either between or within groups. The limited significance could indicate that since participants had similar 
experiences of smartphone use, the age of access to smartphone technology did not result in different attitudes toward the merits of smartphones for learning.

\subsection{Students' Perceptions Regarding Their Future Intentions to Use Smartphones in Their Studies}

The evidence revealed correlations between items and not between or within groups. Based on these findings, the last research question aims to report on participants' perceptions of their intentions to use smartphones in their future studies. Two survey items were selected: "I will continue to use my smartphone in future classes" and "When I graduate, I intend to teach students to use their smartphones in my class."

Table 9 reports that 28 students out of 189 strongly agreed on using their smartphones in future classes. In addition, while 63 participants agreed, 62 neither agreed nor disagreed. Ten participants strongly disagreed, saying that they would not continue to use their smartphones in future classes, and 26 disagreed.

Table 9. Frequency: I will continue to use my smartphone in future classes.

\begin{tabular}{|c|c|c|c|c|c|}
\hline & & Frequency & Percent & $\begin{array}{c}\text { Valid } \\
\text { Percent }\end{array}$ & $\begin{array}{c}\text { Cumulative } \\
\text { Percent }\end{array}$ \\
\hline \multirow{6}{*}{ Valid } & $\begin{array}{l}\text { Strongly } \\
\text { agree }\end{array}$ & 28 & 14.8 & 14.8 & 14.8 \\
\hline & Agree & 63 & 33.3 & 33.3 & 48.1 \\
\hline & $\begin{array}{l}\text { Neither agree } \\
\text { nor disagree }\end{array}$ & 62 & 32.8 & 32.8 & 81.0 \\
\hline & Disagree & 26 & 13.8 & 13.8 & 94.7 \\
\hline & $\begin{array}{l}\text { Strongly } \\
\text { disagree }\end{array}$ & 10 & 5.3 & 5.3 & 100.0 \\
\hline & Total & 189 & 100.0 & 100.0 & \\
\hline
\end{tabular}

While research suggests that students use smartphones in their classes [36,37], Table 10 reports that the responses were skewed to either "strongly disagree" $(n=32)$ or "disagree" $(n=53)$. While 42 participants neither agreed nor disagreed, 47 agreed, and the remaining 15 strongly agreed. As the literature review discussed, smartphones afford multilayered opportunities for students to engage with learning needs and contexts [37,38]. Surprisingly, Table 10 indicates that while participants used technology for learning, they did not seem to agree with the need to allow their learners to gain such smartphone-afforded positive experiences.

Table 10. Frequency: When I graduate, I intend to teach students to use a smartphone in my classes.

\begin{tabular}{|c|c|c|c|c|c|}
\hline & & Frequency & Percent & $\begin{array}{l}\text { Valid } \\
\text { Percent }\end{array}$ & $\begin{array}{c}\text { Cumulative } \\
\text { Percent }\end{array}$ \\
\hline \multirow{6}{*}{ Valid } & $\begin{array}{l}\text { Strongly } \\
\text { agree }\end{array}$ & 15 & 7.9 & 7.9 & 7.9 \\
\hline & Agree & 47 & 24.9 & 24.9 & 32.8 \\
\hline & $\begin{array}{l}\text { Neither agree } \\
\text { nor disagree }\end{array}$ & 42 & 22.2 & 22.2 & 55.0 \\
\hline & Disagree & 53 & 28.0 & 28.0 & 83.1 \\
\hline & $\begin{array}{l}\text { Strongly } \\
\text { disagree }\end{array}$ & 32 & 16.9 & 16.9 & 100.0 \\
\hline & Total & 189 & 100.0 & 100.0 & \\
\hline
\end{tabular}

\section{Discussion}

The convergence of various technologies into one small device, the smartphone, allows users to complete a wide range of digital tasks and activities anytime and anywhere. While previous research was concerned with gender-based digital practices, more recent studies have provided an overview of smartphone practices across age groups. This paper on 
undergraduate female Emirati pre-service teacher students adds to this field of research by clarifying the age at which they accessed their first smartphone and its impact on their perceptions of the educational utility of the smartphone. This information is especially important for teachers, who might use the smartphone not only for their own learning but also for the classes they teach and the learning process of their future students, providing them with an incentive to keep up with technology and its educational implications.

The distribution of participants across the years of study was adequate, providing a reliable overview of the students' perceptions of the smartphone as a learning device. However, in terms of age distribution, there was a skewness toward younger participants aged 18-20. It is also possible that, although the questions asked whether smartphones should be used by the students in the classroom, the survey items did not correctly capture the participants' feelings about smartphones as a learning tool.

The evidence presented in Table 5 seems to suggest that as 18-20-year-old participants $(n=78)$ journey through the four-year teacher program, they may gain a better appreciation for technology integration in the classroom and may be more attuned to primary students' smartphone skills and abilities. It may also be that they have more experience in an actual classroom, such as with student teaching, which would allow them to observe the use of technology in the classroom and the many applications it can have. The authors aim to continue to survey these first-year students until they graduate. The hypothesis for that future study would be that, as these participants become more exposed to teaching practices and technology integration, they will be able to deliver more mobile learning or blended learning experiences in the classroom. Another area for future research might be how the implementation of virtual learning and their ideas about it change considering the current pandemic.

Regarding students' general opinion about using their smartphones in class, a small majority of younger participants seemed to either strongly agree or agree with the statement. However, the evidence could be inconclusive as 47 participants (31\%) neither agreed nor disagreed with using smartphones in class. Additionally, since this question did not specify that smartphones would be used for educational purposes, it would be worth revisiting it to attempt to procure more conclusive data.

Correlation analysis between the age at which students received their first smartphones and their perception of the devices' usefulness or ease of use was also inconclusive. However, both correlation analyses revealed a strong association between students' perceptions of smartphone utility and the perceived ease of use in learning with the devices and liking learning with a smartphone, which is logical: it is normal for us to enjoy things we are good at and find useful.

Likewise, a one-way ANOVA was conducted to compare the means between age groups and the participants' responses to the eight identified variables regarding learning with smartphones. There were no significant differences between the groups. It could be hypothesized that since $66.7 \%$ of the participants were aged 18-26, they all agreed that learning with a smartphone would be useful because the age gap was not significant. Past research notes that there are some differences in technology use with age, but all participants here were part of the same generational cohort; thus, it is possible that the range of ages was not statistically significant.

The findings seem to suggest that for this particular group of participants, using a smartphone is a normal daily activity. It may be possible that because they use their smartphones on a regular basis, these participants have accepted smartphone technology to the extent that they have become indifferent to this tool and its features and services; thus, it did not occur to them that it could be useful in the classroom. Harba [38] reported that $40 \%$ of Syrian learners in a higher education context agreed that the effectiveness of learning with a cell phone was high. Similarly, Baek et al. [39] reported that $47 \%$ of the Korean mothers they surveyed agreed that "smartphone use is helpful in the aspect of learning" (p. 128). Our findings reveal that 38\% of female Emirati pre-service teacher 
undergraduates agreed that students should be able to use their smartphones in class, but since the type of use was not specified, the number may in fact be higher.

\subsection{Limitations}

Along with the previously noted non-specificity of the questions, there are a few other limitations to this study. Using a single institution for this study did not present a general overview of all pre-service teachers currently completing their teaching programs. Future research could engage more UAE institutions in collaborating in order to gain a wider perspective of undergraduate students' perceptions of smartphone-assisted learning. It could also delve further into pre-service teachers' opinions of different types of learning activities for their students and for themselves.

Similarly, although the sample size could be deemed acceptable, the spread between age groups was not large enough. The larger proportions of participants were aged 18-20 $(n=67), 21-23(n=60)$, and 24-26 $(n=32)$. The remaining 30 participants were spread across the ages of 27 and 47 . The proportion is more significant with the age of access to a smartphone. Nine students were aged 1-5 when they had access to their first smartphone. Thirteen participants were aged 6-10 and 35 were aged 11-15. The largest group comprised participants of ages 16-20 $(n=118)$, and the remaining 14 were aged 21 and above. It would have been more informative if the number of participants was equally spread across the selected age groups and perhaps, as noted above, with a wider spread of ages, although this might be hard to achieve with a population of pre-service teachers.

In addition, this study primarily reports quantitative evidence. However, using interviews and group discussions to generate qualitative results may present challenges. Participants may have homogenous opinions, or they may be passive contributors and decline to provide opinions. In either case, there would be very little valuable information acquired if this occurred. It is highly recommended that researchers in Middle Eastern contexts develop suitable strategies for conducting group discussions with female undergraduate students and that this qualitative approach to research be utilized in further studies [40].

\subsection{Implications for Future Research and Practice}

Based on evidence from the previous literature and this study, further research on the impact of age on smartphone use experience is warranted, although such research as it relates to gender may not be. As participants in studies access smartphones at increasingly younger ages on average, it would be informative to understand the educational advantage that such exposure affords these younger learners. Van Deursen et al. [9] concurred by reporting that as participants transition toward an older age group, they are likely to become more skilled with technology use, and it is apparent that this technology can be used educationally. Another avenue for research would be exploring the activities that are useful in an educational context for different ages and to what extent, and how teachers and pre-service teachers view these activities.

The current findings also contribute to the body of knowledge because they provide an approximation of pre-service teachers' familiarity with and perceptions of the educational benefit of using smartphones for learning, for themselves and, to some extent, for their students. In addition, it may be possible that, as participants had experiences with smartphones at a younger age, they may have gained more competence in operating a smartphone to enhance their mobile learning experiences. This information is useful because it may result in best practices around how children are initially introduced to such devices. The implication of such a scenario is that teachers will need to improve their smartphone expertise to be able to meet the mobile learning skills of their students and help their students take advantage of all the resources that a mobile platform places at their fingertips. In Korea, $87 \%$ of people over three years old are reportedly smartphone users [39]. Given that some learners may have such prior technological exposure, educators may face increasing challenges, thus warranting future research questions investigating the 
expertise these students bring to and demand from the information and communications technology classroom.

Finally, further research in age of access to a smartphone may result in investigation in two emerging field of research; COVID-19 related studies and wellbeing. In relation to the latter, the Fear of Missing out (FOMO) and other psychological side-effects may have impacts on Middle Eastern undergraduates' risk of "addictive technological behavior" [41], [p.84]. In relation to the impact of COVID-19 on smartphone use, the literature is beginning to provide some evidence. For example, [42] reports smartphone technology has decreased social distancing by increasing social connectivity, which had an impact on students wellbeing. With COVID-19 becoming a new constant (i.e., endemic) scenario, further research in this area is warranted. Likewise, more research is also needed on the impact of national IT development and policies and the roles these elements play in students and teachers' adoption and perceptions of smartphones regarding their usefulness, effort expectancy, relative advantage, etc., for educational purposes.

\section{Conclusions}

In sum, the importance of using technology such as smart phones in the classroom is evident. Educators and policymakers must embrace this tool and incorporate digital literacy into our curriculum and teaching styles. It is important to use technology such as smart devices/phones in the classroom not only to facilitate learning but also teach the appropriate etiquette and skill development surrounding the environment of online applications and devices. When it comes to accessibility, these tools are evolving at an incredible rate, and it is essential that educators maintain relevance. The opportunities that exist within the technologies themselves are only beginning to take shape in the classroom and as advances are inevitable, educators must embrace these technologies as a plethora of relevant information and capacity exists within them. The recent influx in technology has resulted in a generation that has grown up surrounded by it, and although these affects are still widely debated, it is apparent that this new generation has embraced its promise and so too must those who are working in education and directing future educational policy.

In the past, research on the perceptions and use of technology was focused on gender. However, as technology becomes ubiquitous and accessible to younger users, age-centered research is becoming more relevant. The evidence confirms that participants with access to smartphones from an early age seem to find smartphone technology conducive to learning and seem to appreciate its usefulness, which is similar to young pre-service teachers. Having more than one smartphone does not seem to impact the appreciation of smartphones as a learning device. The literature indicates that smartphone consumers are becoming younger, and the possible impact of this early acquisition of devices on the need or desirability of using them in the classroom requires further research. The evidence from this study brings us a step closer to understanding Emirati female undergraduates' smartphone perceptions and suggests a lead into further research in this area.

Author Contributions: Conceptualization, N.G. and D.L.; methodology, N.G.; software, SPSS and Qualtrics; validation, N.G. and D.L.; formal analysis, N.G.; investigation, N.G.; resources, N.G. and D.L.; data curation, N.G.; writing-original draft preparation, N.G. and D.L.; writing-review and editing, N.G. and D.L.; visualization, N.G. and D.L.; supervision, N.G. and D.L.; project administration, N.G.; funding acquisition, No Funding was received. All authors have read and agreed to the published version of the manuscript.

Funding: This research received no external funding.

Institutional Review Board Statement: In this section, please add the Institutional Review Board Statement and approval number for studies involving humans or animals. Please note that the Editorial Office might ask you for further information. Please add "The study was conducted according to the guidelines of the Declaration of Helsinki, and approved by the Institutional Review Board (or Ethics Committee) of Emirates College of Advanced Education (Approved 11 November 2015). 
Informed Consent Statement: Informed consent was obtained from all subjects involved in the study. Implied written informed consent has been obtained from the patient(s) as part of the digital survey process to publish this paper.

Data Availability Statement: The data are available upon request.

Acknowledgments: The authors wish to acknowledge guidance and support from Parkman, S.

Conflicts of Interest: The authors declare no conflict of interest.

\section{References}

1. Prensky, M. Digital natives, digital immigrants. On the Horizon 2001, 9, 1-6.

2. McNeely, B. Using Technology as a Learning Tool, Not Just a Cool New Thing. Available online: https://www.educause.edu/ research-and-publications/books/educating-net-generation/using-technology-learning-tool-not-just-cool-new-thing (accessed on 5 November 2019).

3. Hashim, K.F.; Tan, F.B.; Rashid, A. Adult learners' intention to adopt mobile learning: A motivational perspective. Br. J. Educ. Technol. 2015, 46, 381-390. [CrossRef]

4. Norris, C.; Hossain, A.; Soloway, E. Using smartphones as essential tools for learning. Educ. Technol. 2011, 51, 18-25.

5. Kadry, S.; Roufayel, R. How to Use Effectively Smartphone in the Classroom. In Proceedings of the 2017 IEEE Global Engineering Education Conference, Athens, Greece, 25-28 April 2017; pp. 43-439.

6. The World Bank. Mobile Cellular Subscriptions-United Arab Emirates. Available online: https://data.worldbank.org/indicator/ IT.CEL.SETS?locations=AE (accessed on 17 December 2019).

7. Ipsos OTX MediaCT. Our Mobile Planet: United Arab Emirates: Understanding the Mobile Consumer. Available online: http:/ / www.mmaglobal.com/files/UAE_English.pdf (accessed on 18 December 2019).

8. Symantec Report. (Edeleman Intelligence) Norton's My First Device Report. Available online: https://now.symassets.com/ content/dam/norton/global/pdfs/reports/Norton_My_First_Device_Report_Oct_2018_Final.pdf (accessed on 25 July 2020).

9. Van Deursen, A.; Bolle, C.L.; Hegner, S.M.; Kommers, P. Modeling habitual and addictive smartphone behavior: The role of smartphone usage types, emotional intelligence, social stress, self-regulation, age and gender. Comput. Hum. Behav. 2015, 45, 411-420. [CrossRef]

10. Nofziger, H. Platform, Not Gender, Drives Gamer Differences-EEDAR. Available online: https:/ /www.gamesindustry.biz/ articles/2014-10-30-platform-not-gender-drives-gamer-differences-eedar (accessed on 10 December 2018).

11. Jenkin, M. Rise of the Silver Games: You Don't Have to be Young to Play Video Games. Available online: https://www. theguardian.com/society/2014/jul/15/silver-gamers-older-people-technology (accessed on 25 November 2019).

12. Al-Showarah, S.; Al-Jawad, N.; Sellahewa, H. Effects of user age on smartphone and tablet use, measured with an eye-tracker via fixation duration, scan-path duration, and saccades proportion. In Universal Access in Human-Computer Interaction. Universal Access to Information and Knowledge. UAHCI 2014; Stephanidis, C., Antona, M., Eds.; Springer: Cham, Switzerland, 2014; Volume 8514, pp. 3-14. [CrossRef]

13. Sarwar, M.; Soomro, T.R. Impact of smartphone's on society. Eur. J. Sci. Res. 2013, 98, 216-226.

14. United Nations, Department of Economic and Social Affairs, Population Division. World Population Ageing 2013. Available online: https://www.un.org/en/development/desa/population/publications/pdf/ageing/WorldPopulationAgeing2013.pdf (accessed on 25 June 2020).

15. International Telecommunications Union. ITU Key 2005-2015 ICT Data. Available online: http://www.itu.int/en/ITU-D/ Statistics/Pages/stat/default.aspx (accessed on 7 December 2019).

16. Park, J.H.; Park, M. Smartphone use patterns and problematic smartphone use among preschool children. PLoS ONE 2021, 16, e0244276. [CrossRef]

17. Lavanya, K.; Varalakshmi, R. Smartphone usage patterns of college students. Age 2019, 16, 16.

18. Central Intelligence Agency. The World Factbook: United Arab Emirates. Available online: https://www.cia.gov/the-worldfactbook/countries/united-arab-emirates (accessed on 25 July 2021).

19. Global System Global System for Mobile Communications. The Mobile Economy Middle East and North Africa. 2019. Available online: https:/ / www.gsma.com/mobileeconomy/wp-content/uploads/2020/03/GSMA_MobileEcodomy2020_MENA_Eng.pdf (accessed on 25 July 2020).

20. McGregor, G.; Bartle, E. Using Mobile Serious Games Technology to Enhance Student Engagement and Learning in a Postgraduate Ethics Classroom. In Proceedings of the 15th World Conference on Mobile and Contextual Learning, mLearn 2016, Sydney, Australia, 24-26 October 2016.

21. Ciampa, K. Learning in a mobile age: An investigation of student motivation. J. Comput. Assist. Learn. 2014, 30, 82-96. [CrossRef]

22. Baran, E. A review of research on mobile learning in teacher education. J. Educ. Techno. Soc. 2014, 17, 17.

23. Okojie, M.; Olinzock, A.A.; Okojie-Boulder, T.C. The pedagogy of technology integration. J. Technol. Stud. 2006, 32, 66-71. [CrossRef]

24. Newhouse, C.P.; Williams, P.J.; Pearson, J. Supporting mobile education for pre-service teachers. Australas. J. Educ. Technol. 2006, 22, 289-311. [CrossRef] 
25. Grant, M.M.; Tamim, S.; Brown, D.B.; Sweeney, J.P.; Ferguson, F.K.; Jones, L.B. Teaching and learning with mobile computing devices: Case study in K-12 classrooms. TechTrends 2015, 59, 32-45.

26. O'Bannon, B.W.; Thomas, K.M. Mobile phones in the classroom: Preservice teachers answer the call. Comput. Educ. 2015, 85, 110-122. [CrossRef]

27. Riddle, J. Working with Parents to Successfully Integrate Personal Handheld Mobile Technology in the K-12 Classroom. In Proceedings of Society for Information Technology E Teacher Education International Conference; Resta, P., Smith, S., Eds.; Association for the Advancement of Computing in Education (AACE): Austin, TX, USA, 2017; pp. 1757-1762. Available online: https: / /www.learntechlib.org/primary/p/177932/ (accessed on 2 November 2021).

28. Leinonen, T.; Keune, A.; Veermans, M.; Toikkanen, T. Mobile apps for reflection in learning: A design research in K-12 education. Br. J. Educ. Technol. 2016, 47, 184-202. [CrossRef]

29. Christensen, R.; Knezek, G. Contrasts in Openness Toward Mobile Learning in the Classroom: A Study of Elementary, Middle and High School Teachers. In Proceedings of the International Association for Development of the Information Society International Conference on Cognition and Exploratory Learning in Digital Age, Algarve, Portugal, 18-20 October 2017.

30. Ameen, N.; Willis, R. An Analysis of the Moderating Effect of Age on Smartphone Adoption and Use in the United Arab Emirates. In Proceedings of the UK Academy for Information Systems Conference, 2018; p. 1. Available online: https: / / aisel.aisnet.org/ukais2018/1 (accessed on 31 January 2020).

31. Ma'azer Al Fawareh, H.; Jusoh, S. The use and effects of smartphones in higher education. Ijim 2017, 11, 103.

32. Qualtrics. Available online: https:/ / www.qualtrics.com (accessed on 31 January 2018).

33. IBM Corp. Released 2019. IBM SPSS Statistics for Windows, Version 26.0; IBM Corp: Armonk, NY, USA, 2019.

34. Taber, K.S. The use of Cronbach's alpha when developing and reporting research instruments in science education. Res. Sci. Educ. 2018, 48, 1273-1296. [CrossRef]

35. Laerd Statistics. One-Way ANOVA. Available online: https://statistics.laerd.com/statistical-guides/one-way-anova-statisticalguide (accessed on 25 July 2020).

36. Matsumoto, Y. Student self-initiated use of smartphones in multilingual writing classrooms: Making learner agency and multiple involvements visible. Mod. Lang. J. 2021, 105, 142-174. [CrossRef]

37. Sahlström, F.; Tanner, M.; Valasmo, V. Connected youth, connected classrooms. Smartphone use and student and teacher participation during plenary teaching. Learn. Cult. Soc. Interact. 2019, 21, 311-331.

38. Harba, A.M. Modern educational technology: Educational usages of cell phone as perceived by students of education faculties. J. Sch. Educ. Technol. 2012, 8, 24-32.

39. Baek, Y.; Lee, J.; Kim, K. A study on smart phone use condition of infants and toddlers. Int. J. Smart Home 2013, 7, 123-132. [CrossRef]

40. Clark, J.A. Field research methods in the Middle East. PS Political Sci. Politics 2006, 39, 417-424.

41. O'Connell, C. How FOMO (Fear of Missing Out), the Smartphone, and Social Media May Be Affecting University Students in the Middle East. N. Am. J. Psychol. 2020, 22, 83-102.

42. David, M.E.; Roberts, J.A. Smartphone Use during the COVID-19 Pandemic: Social Versus Physical Distancing. Int. J. Environ. Res. Public Health 2021, 18, 1034. 